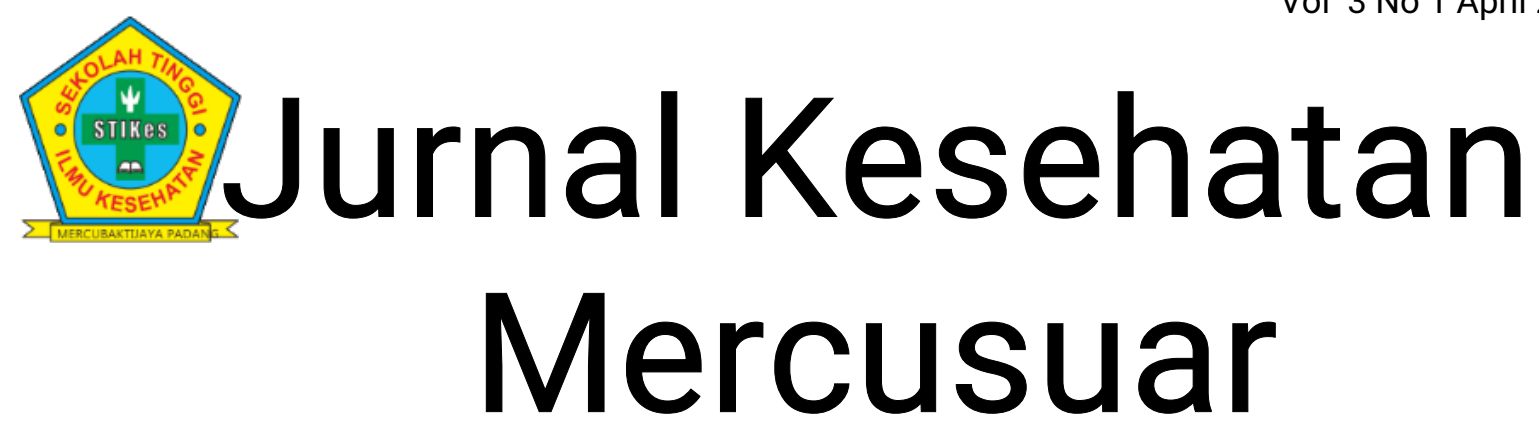

Avalilable Online http://jurnal.mercubaktijaya.ac.id/index.php/mercusuar

\title{
HUBUNGAN ANEMIA DENGAN FUNGSI KOGNITIF PADA PASIEN YANG MENJALANI TERAPI HEMODIALISIS DI RST DR. REKSODIWIRYO PADANG
}

\author{
Ria Desnita ${ }^{1 *}$, Mira Andika ${ }^{2}$, Miranti Wulandari ${ }^{3}$ \\ 1,2,3Program Studi SI Keperawatan, STIKes MERCUBAKTIJAYA Padang \\ ${ }^{\star}$ Email : ria.desnita18@gmail.com
}

\begin{abstract}
One complication of Terminal Kidney Failure undergoing hemodialysis is anemia. Anemia causes impaired oxygen transfer to the brain which results in decreased concentration and decreased cognitive function. The purpose of this study was to determine the relationship of anemia with cognitive function in patients undergoing hemodialysis therapy at RST Dr. Reksodiwiryo Padang. This type of research is cross sectional. This research was conducted in December 2018 - July 2019 in Dr. RST Hemodialysis Room Reksodiwiryo Padang. The sample in this study amounted to 42 people using the method of "purposive sampling". The research instrument used was the Mini Mental State Exam (MMSE) questionnaire. Univariate analysis is displayed in the frequency distribution and bivariate tables using the chisquare test with 95\% confidence. The results showed more than half (61.9\%) of respondents experienced severe cognitive impairment, the majority (78.6\%) of respondents experienced anemia and there was an association of anemia with cognitive function in patients undergoing hemodialysis therapy at RST Dr. Padang Reksodiwiryo ( $p$ <0.05). Conclusions from the results of anemia research affect the cognitive function of Terminal Kidney Failure patients undergoing hemodialysis therapy. It is expected that nurses can provide education to patients on how to overcome anemia and maintain cognitive function.
\end{abstract}

Keywords: Terminal Kidney Failure, Anemia, Cognitive Function, Hemodialysis

\section{ABSTRAK}

Salah satu komplikasi penyakit Gagal Ginjal Terminal yang menjalani hemodialisis adalah anemia. Anemia menyebabkan transfer oksigen ke otak terganggu yang berdampak pada penurunan konsentrasi dan penurunan fungsi kognitif. Tujuan dari penelitian ini adalah untuk mengetahui hubungan anemia dengan fungsi kognitif pada pasien yang menjalani terapi Hemodialisis di RST Dr. Reksodiwiryo Padang. Jenis penelitian ini adalah cross sectional. Penelitian ini 
dilakukan pada bulan Desember 2018 - Juli 2019 di ruangan Hemodialisa RST Dr. Reksodiwiryo Padang. Sampel pada penelitian ini berjumlah 42 orang dengan menggunakan metode "purposive sampling". Instrumen penelitian yang digunakan adalah kuesioner Mini Mental State Exam (MMSE). Analisa secara univariat ditampilkan pada tabel distribusi frekuensi dan bivariat dengan menggunakan uji chisquare dengan kepercayaan $95 \%$. Hasil penelitian menunjukkan lebih dari separuh $(61,9 \%)$ responden mengalami gangguan fungsi kognitif berat, sebagian besar $(78,6 \%)$ responden mengalami anemia dan terdapat hubungan anemia dengan fungsi kognitif pada pasien yang menjalani terapi hemodialisis di RST Dr. Reksodiwiryo Padang $(p<0,05)$. Kesimpulan dari hasil penelitian anemia mempengaruhi fungsi kognitif pasien Gagal Ginjal Terminal yang menjalani terapi hemodialisis. Diharapkan kepada perawat dapat memberikan edukasi kepada pasien tentang cara mengatasi anemia dan mempertahankan fungsi kognitif.

Kata Kunci: Gagal Ginjal Terminal, Anemia, Fungsi Kognitif, Hemodialisis

\section{PENDAHULUAN}

Gagal Ginjal Terminal merupakan terjadinya penurunan pada fungsi ginjal secara progresif dan tidak dapat pulih kembali. Gagal Ginjal Terminal menyebabkan tubuh gagal untuk mempertahankan metabolisme dan keseimbangan cairan elektrolit yang dapat mengakibatkan terjadinya peningkatan ureum di dalam darah. Gagal Ginjal Terminal mempunyai karakteristik bersifat menetap, tidak bisa disembuhkan, dan memerlukan pengobatan seperti terapi hemodialisis, dialisis peritonial, transplantasi ginjal dan rawat jalan dengan waktu yang lama(Black \& Hawk, 2014)

Menurut United State Renal Data System (2016) prevalensi penyakit gagal ginjal kronik di dunia terus meningkat setiap tahunnya yaitu $20-25 \%$, sehingga diperkirakan 1 dari 10 orang di dunia mengalami penyakit gagal ginjal terminal. Di Indonesia prevalensi angka kejadian gagal ginjal terminal pada usia 15 tahun ke atas adalah $0,2 \%$ dari seluruh penduduk Indonesia (Kementrian Kesehatan RI, 2013).
Sementara menurut Riset Kesehatan Dasar 2018, prevalensi penderita yang mengalami gangguan ginjal tahap akhir mengalami peningkatan yaitu dari $0,2 \%$ menjadi 3,8\% (Kementrian Kesehatan Rl, 2018). Prevalensi Gagal Ginjal Terminal di Sumatera Barat termasuk kedalam 20 besar dari 35 Provinsi yang ada di Indonesia (Kementrian Kesehatan RI, 2018)

Penderita Gagal Ginjal Terminal membutuhkan terapi pengganti ginjal untuk kelangsungan hidupnya, salah satunya dengan terapi hemodialisis. Hemodialisis merupakan terapi untuk mengeluarkan sisa-sisa metabolisme atau cairan intrasel atau ekstrasel kedalam keadaan normal melalui aliran darah. Pada hemodialisis, darah yang mengandung toksin akan dialirkan ke dialiser, dibersihkan dan kemudian dikembalikan ke tubuh pasien. Salah satu aspek penting hemodialisis adalah menjaga dan mempertahankan akses darah yang adekuat. Terapi hemodialisis harus dijalani penderita PGTA seumur 
hidup, rata-rata penderita PGTA menjalani hemodialisis yaitu selama 10-12 jam per minggu (Black \& Hawk, 2014)

Meskipun hemodialisis aman dan bermanfaat untuk pasien, tetapi tindakan ini tidak akan mengembalikan semua fungsi ginjal. Terapi hemodialisis akan menimbulkan stres fisik seperti kelelahan, sakit kepala, dan keluar keringat dingin akibat tekanan darah yang menurun. Efek hemodialisis juga akan mempengaruhi keadaan psikologis, yang mana akan menimbulkan masalah seperti depresi, kejenuhan, prilaku tidak kooperatif dan bunuh diri. Pasien akan mengalami gangguan pada konsentrasi, proses berfikir atau gangguan pada fungsi kognitifnya. Pasien Gagal Ginjal Terminal yang menjalani hemodialisis akan mengalami penurunan neuropatologis pada otak yang terjadi secara paralel (Baykan \& Yargic, 2012)

Fungsi kognitif mencakup proses berfikir, kapasitas memori dan kemampuan untuk memperhatikan sesuatu. Gangguan kognitif dicirikan dengan kemunduran kognitif yang merupakan hasil dari kasus-kasus trauma otak, penyakit atau berhubungan dengan zat-zat yang mengandung racun (Halgin, 2010).

Banyak faktor yang dapat mempengaruhi gangguan fungsi kognitif pada penderita Gagal Ginjal Terminal yang menjalani terapi hemodialisis diantaranya stres fisik, permasalahan psikologis dan kondisi anemia (Jung et al., 2013)

$$
\text { Anemia }
$$
merupakan

komplikasi penyakit Gagal Ginjal Terminal yang sering terjadi, bahkan dapat terjadi lebih awal dibandingkan komplikasi PGTA lainnya. Hal ini disebabkan oleh karena menurunnya ketahanan hidup sel darah merah maupun defisiensi eritropoetin (Brunner \& Suddarth, 2014), berkurangnya kadar hemoglobin di dalam darah akibat pengambilan darah untuk pemeriksaan laboratorium, retensi darah pada dialiser, defisiensi besi, pemendekan umur sel darah merah, anemia akibat toksik uremia, serta akibat inflamasi atau perdarahan (Babitt \& Lin, 2012)

Anemia mengindikasikan meningkatnya resiko mobilitas buruk, meningkatnya frailty, menurunnya fungsi eksekutif dan menurunnya fungsi kognitif. Anemia dapat menyebabkan transfer oksigen yang memperlancar metabolisme sel-sel otak menjadi terhambat. Sehingga terjadi metabolisme lemak myelin yang menghantar impuls saraf terganggu dan menyebabkan konsentrasi ikut terganggu (Papalia, 2009)

Berdasarkan survey awal yang dilakukan peneliti pada tanggal 10 Desember 2018, didapatkan hasil dari observasi dan wawancara pada 10 orang pasien, $40 \%$ pasien datang dengan keadaan normal, serta bisa diajak untuk berkomunikasi seperti biasa, pasien tetap bekerja seperti biasa meskipun harus rutin menjalani terapi hemodialisis 2 kali/minggu dengan kadar $\mathrm{HB} \geq 11$ $\mathrm{gr} / \mathrm{dl}$. Sedangkan $60 \%$ pasien datang dengan kondisi tampak lesu, kehilangan nafsu makan, mudah lelah dan terlihat pucat yang disebabkan oleh kadar HB yang menurun < $11 \mathrm{gr} / \mathrm{dl}$.

Sementara pada fungsi kognitif dari 10 pasien didapatkan 
40\% pasien mengatakan tidak mengalami penurunan daya ingat dengan kadar $\mathrm{HB} \geq 11 \mathrm{gr} / \mathrm{dl}$, sedangkan $60 \%$ pasien lainnya mengatakan mengalami penurunan daya ingat seperti pasien lupa dengan jadwal makannya, lupa apakah sudah mandi atau belum dengan kadar $\mathrm{HB}<11 \mathrm{gr} / \mathrm{dl}$.

Berdasarkan fenomena diatas, peneliti melihat adanya perubahan fungsi kognitif pada pasien hemodialisis yang kemungkinan dipengaruhi oleh anemia. Oleh karena itu peneliti tertarik untuk melakukan penelitian "Hubungan Anemia Dengan Fungsi Kognitif Pada Pasien Yang Menjalani Terapi Hemodialisis di RST Dr. Reksodiwiryo Padang"

\section{METODE PENELITIAN}

Jenis dari penelitian ini adalah deskriptif analitik dengan desain cross sectional, dimana data yang terdiri dari variabel bebas (Anemia) dan variabel terikat (fungsi kognitif pada pasien yang menjalani terapi hemodialisis). Sampel pada penelitian ini adalah pasien Gagal Ginjal Terminal yang menjalani terapi hemodialisis di RST Dr. Reksodiwiryo sebanyak 42 orang. Teknik pengambilan sampel dalam penelitian ini adalah purposive sampling. Kriteria inklusi pada penelitian ini adalah klien kooperatif dan dapat berkomunikasi dengan baik, klien bisa baca tulis, usia 30-60 tahun. Kriteria ekslusinya adalah klien yang mengalami penurunan kesadaran, gangguan penglihatan dan pendengaran, klien yang mengalami nyeri, pusing, mual dan muntah selama hemodialisis berlangsung.

Instrumen yang digunakan untuk menilai fungsi kognitif pasien adalah Mini Mental State Exam (MMSE). Sedangkan untuk data anemia didapatkan dengan melihat data hasil pemeriksaan $\mathrm{Hb}$ pasien. Untuk melihat hubungan antara anemia dengan fungsi kognitif pada pasien yang menjalani hemodialisis dilakukan uji chi square.

\section{HASIL DAN PEMBAHASAN}

Gambaran kejadian anemia pada Pasien Gagal Ginjal Terminal yang Menjalani Terapi Hemodialisis di RST Dr. Reksodiwiryo Padang dapat dilihat pada table 1 berikut.

Tabel 1

Kejadian Anemia pada Pasien yang Menjalani Hemodialisis di RST Dr. Reksodiwiryo Padang

Berdasarkan tabel 1 diatas dapat dilihat bahwa lebih dari separoh (78,6\%) responden mengalami anemia di RST Dr. Reksodiwiryo Padang.

Gambaran fungsi kognitif pada pasien yang menjalani terapi hemodialysis di RST Dr. Reksodiwiryo Padang terdapat pada tabel berikut.

\section{Tabel 2.}

Gambaran Fungsi Kognitif Pasien yang Menjalani Terapi Hemodialisis di RST

$$
\text { Dr. Reksodiwiryo Padang }
$$

\begin{tabular}{|c|c|c|}
\hline Fungsi Kognitif & $f$ & $\%$ \\
\hline Berat & 26 & 61.9 \\
\hline Sedang & 9 & 21.4 \\
\hline Normal & 7 & 16.7 \\
\hline Total & 42 & 100 \\
\hline
\end{tabular}

Berdasarkan tabel 2 di atas dapat dilihat bahwa lebih dari separoh (61,9\%) responden 
mengalami gangguan fungsi kognitif berat di RST Dr. Reksodiwiryo Padang.

Hubungan anemia dengan Ffungsi kognitif pada pasien Gagal

\begin{tabular}{|c|c|c|}
\hline Kejadian Anemia & $f$ & $\%$ \\
\hline Anemia & 33 & 78.6 \\
\hline Tidak anemia & 9 & 21.4 \\
\hline Total & 42 & 100 \\
\hline
\end{tabular}

Berdasarkan tabel 3 di atas dapat dilihat bahwa sebagian besar $(69,7 \%)$ responden dengan anemia mengalami gangguan fungsi kognitif berat dan sebagian besar $(44,4 \%)$ responden tidak anemia mengalami gangguan fungsi kognitif ringan. Hasil uji statistik (Chi Square) diperoleh nilai $p=0.033$ ( $P$ value $\leq$ 0.05), maka dapat disimpulkan bahwa terdapat hubungan anemia dengan fungsi kognitif pada pasien yang menjalani terapi hemodialisis di RST Dr. Reksodiwiryo Padang.

Berdasarkan hasil penelitian diperoleh lebih dari separoh (78,6\%) pasien mengalami anemia pada pasien yang menjalani terapi hemodialisis di RST Dr. Reksodiwiryo Padang. Hasil penelitian ini mendukung penelitian sebelumnya yang dilakukan oleh (Astrini et al., 2013) tentang hubungan kadar hemoglobin $(\mathrm{Hb})$, indeks massa tubuh (IMT) dan tekanan darah dengan kualitas hidup pasien gagal ginjal kronik
Ginjal Terminal yang Menjalani Terapi Hemodialisis di RST Dr. Reksodiwiryo Padang terdapat pada tabel berikut.

\section{Tabel 3}

Hubungan Anemia dengan Fungsi Kognitif pada Pasien yang Menjalani Hemodialisis di RST Dr. Reksodiwiryo Padang

\begin{tabular}{|c|c|c|c|c|c|c|c|c|c|}
\hline \multirow{3}{*}{$\begin{array}{l}\text { Kejadia } \\
\text { Anemia }\end{array}$} & \multicolumn{6}{|c|}{ Fungsi Kognitif } & \multirow{2}{*}{\multicolumn{2}{|c|}{ Total }} & \multirow[t]{2}{*}{$\begin{array}{c}P \\
\text { value }\end{array}$} \\
\hline & \multicolumn{2}{|c|}{ Berat } & \multicolumn{2}{|c|}{ Sedang } & \multicolumn{2}{|c|}{ Normal } & & & \\
\hline & 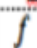 & $\%$ & $f$ & $\%$ & $f$ & $\%$ & $f$ & $\%$ & \\
\hline Anemia & 23 & 69,7 & 7 & 21,2 & 3 & 9,1 & 33 & 100 & \\
\hline Tidak anemia & 3 & 33,3 & 2 & 22,2 & 4 & 44,4 & 9 & 100 & 0.033 \\
\hline Total & 26 & 61,9 & 9 & 21,4 & 7 & 16,7 & 42 & 100 & \\
\hline
\end{tabular}

yang menjalani hemodialisis di RSUD Dokter Soedarso Pontianak Bulan April 2013 diperoleh hasil sebanyak $\quad(57,8 \%)$ responden mengalami anemia dengan kadar $\mathrm{Hb}<11 \mathrm{gr} / \mathrm{dl}$. Hal ini juga sejalan dengan penelitian yang dilakukan oleh (Septiwi, 2011) tentang hubungan antara adekuasi hemodialisa dengan kualitas hidup pasien hemodialisis di unit hemodialisis RS Prof. Dr. Margono Soekarjo Purwokerto didapatkan $(58,4 \%)$ pasien gagal ginjal kronis yang menjalani hemodialisis mengalami anemia.

Penyebab utama anemia pada pasien penyakit ginjal tahap akhir adalah kurangnya produksi eritropoietin (EPO) karena penyakit ginjalnya. Faktor tambahan termasuk kekurangan zat besi, peradangan akut dan kronik dengan gangguan penggunaan zat besi (anemia penyakit kronik), hiperparatiroid berat dengan konsekuensi fibrosis sumsum 
tulang, pendeknya masa hidup eritrosit akibat kondisi uremia. Selain itu kondisi komorbiditas seperti hemoglobinopati dapat memperburuk anemia (Babitt \& Lin, 2012)

Berdasarkan penelitian diperoleh hasil lebih dari separuh $(61,9 \%)$ responden mengalami gangguan fungsi kognitif berat pada pasien yang menjalani terapi hemodialisis di RST Dr. Reksodiwiryo Padang. Hasil penelitian ini mendukung penelitian sebelumnya yang dilakukan oleh (Herman et al., 2015) tentang hubungan lama hemodialisis dengan fungsi kognitif responden penyakit Ginjal Ginjal Kronik yang Menjalani Hemodialisis di RSUD Abdul Moeloek Bandar Lampung diperoleh hasil sebanyak (63,8\%) responden mengalami gangguan fungsi kognitif berat.

\section{Sementara}

menurut penelitian yang dilakukan oleh (Murray \& Knopman, 2010) tentang gangguan kognitif pada dialisis dan populasi penyakit gagal ginjal kronis didapatkan hasil sebanyak (37\%) responden mengalami gangguan fungsi kognitif berat. Hal ini sama dalam penelitian yang dilakukan oleh (Kurella et al., 2005) tentang gangguan kognitif pada penyakit ginjal kronis didapatkan hasil sebanyak (38\%) mengalami gangguan fungsi kognitif berat.

Penderita gagal ginjal tahap akhir akan mengalami anemia, dimana anemia merupakan komplikasi penyakit gagal ginjal tahap akhir yang sering terjadi, bahkan dapat terjadi lebih awal dibandingkan komplikasi PGTA lainnya. Hal ini disebabkan oleh karena menurunnya ketahanan hidup sel darah merah maupun defisiensi eritropoetin (Brunner \& Suddarth, 2014), berkurangnya kadar hemoglobin di dalam darah akibat pengambilan darah untuk pemeriksaan laboratorium, retensi darah pada dialiser, defisiensi besi, pemendekan umur sel darah merah, anemia akibat toksik uremia, serta akibat inflamasi atau perdarahan (Babitt \& Lin, 2012) Berdasarkan penelitian diperoleh hasil proprosi pasien yang mengalami anemia lebih banyak dengan fungsi kognitif berat yaitu $(69,7 \%)$ dan pasien yang tidak mengalami anemia lebih banyak dengan fungsi kognitif normal yaitu $(44,4 \%)$. Hasil uji statistic (Chi Square) diperoleh nilai $p=0.033(P$ value $\leq$ 0.05), maka dapat disimpulkan bahwa terdapat hubungan anemia dengan fungsi kognitif pada pasien yang menjalani terapi hemodialisis di RST Dr. Reksodiwiryo Padang.

Hasil penelitian ini mendukung penelitian sebelumnya yang dilakukan oleh (Nopriantha \& Kuswardhani, 2018) yaitu tentang kolerasi antara kadar hemoglobin dengan status kognitif pada pasien geriatri di RSUP Sanglah didapatkan hasil adanya kolerasi antara kadar hemoglobin dan status kognitif pada pasien geriatri yang mana pada kondisi anemia akan timbul kondisi hipoksik sehingga tidak hanya akan mempengaruhi fungsi fisik, tetapi juga akan mempengaruhi pada fungsi kognitif. Menurut penelitian yang dilakukan oleh (Nopriantha \& Kuswardhani, 2018) ini mengambil jumlah responden sebanyak 74 orang yang berusia $\geq 60$ tahun dengan kadar hemoglobinnya $<10$ $\mathrm{gr} / \mathrm{dl}$ yang dilihat dari cacatatan 
rekam medik dari responden.

Sementara berbeda dengan hasil penelitian yang dilakukan oleh (Palawe \& Rotty, 2016) yaitu tentang hubungan kadar hemoglobin dengan fungsi kognitif, kualitas tidur, dan lama rawat inap pasien lansia di RSUP Prof Dr. R. D. Kandou Manado didapatan hasil tidak terdapat hubungan antara kadar hemoglobin dengan fungsi kognitif. Hal tersebut disebabkan adanya berbagai faktor yang dapat mempengaruhi fungsi kognitif pada pasien, diantaranya faktor usia, jenis kelamin, pendidikan, riwayat penyakit, lingkungan, gizi dan aktivitas fisik.

Efek langsung anemia pada gangguan fungsi kognitif yaitu ditandai dengan adanya gangguan metabolisme oksidatif pada otak. Gangguan metabolisme oksidatif ini mengakibatkan terjadinya stres oksidatif, dimana ia akan mempengaruhi fungsi otak secara langsung sehingga mengakibatkan terjadinya penurunan pada fungsi kognitif (Rodríguez-Sánchez et al., 2011)

Efek tidak langsung anemia pada fungsi kognitif yakni pada kondisi kadar hemoglobin yang rendah sehingga terjadi penurunan asupan oksigen ke otak. Dengan terjadinya penurunan asupan oksigen ke otak, maka akan mempengaruhi kemampuan mengingat, kemampuan bekerja serta kecepatan otak untuk berpikir sehingga fungsinya secara umum akan terganggu (Putri, 2015)

\begin{tabular}{lcr}
\multicolumn{1}{c}{ Hasil } & penelitian & juga \\
diperoleh & responden & tidak \\
mengalami & anemia & tetapi \\
mengalami & gangguan & kognitif \\
sedang yaitu & $(22,2 \%)$ dan gangguan
\end{tabular}

fungsi kognitif berat (33,3\%), hal tersebut bisa disebabkan karena pengaruh faktor lain seperti faktor usia dimana semakin bertambahnya usia seseorang maka daya ingat seseorang akan semakin menurun, dimana terdapat sebanyak $(66,7 \%)$ responden dengan rentang usia 5160 tahun.

Proses hemodialisis yang lama umumnya akan menimbulkan stres fisik, pasien akan merasakan kelelahan, sakit kepala, dan berkeringat dingin akibat tekanan darah yang turun. Tetapi ini juga akan mempengaruhi keadaan psikologis pasien. Pasien akan mengalami gangguan berpikir dan konsentrasi serta gangguan dalam berhubungan sosial. Semua kondisi tersebut akan menyebabkan menurunnya kualitas hidup pasien penyakit ginjal kronik yang menjalani hemodialisis (Listiyana et al., 2013)

Pasien dengan penyakit ginjal kronik yang menjalani hemodialisis tiga kali seminggu menderita gangguan kognitif sedang hingga berat. Hal ini mungkin dipengaruhi oleh sisa bersihan ureum, efek samping frekuensi hemodialisis tiga kali seminggu, atau kondisi lain yang dapat mempengaruhi fungsi kognitif, seperti depresi, penyakit serebrovaskular, atau penggunaan obat tertentu. Pasien penyakit ginjal kronik akan mengalami gangguan fungsi kognitif seiring dengan bertambah parahnya kerusakan ginjal. Banyak pasien hemodialisis mengalami gangguan fungsi memori, gangguan motorik, dan gangguan perhatian. Penurunan fungsi kognitif pun akan terus mengalami peningkatan seiring bertambahnya usia dan dipengaruhi 
pula oleh faktor resiko penyakit kardiovaskular (Jung et al., 2013)

Analisa peneliti terhadap hasil

penelitian bahwa terbukti terdapat hubungan anemia dengan fungsi kognitif, yang mana terdapat $69,7 \%$ responden mengalami anemia dengan fungsi kognitif berat, 21,2\% responden mengalami anemia dengan fungsi kognitif sedang dan 9,1\% responden mengalami anemia dengan kognitif normal. Hal ini disebabkan karena semakin turunnya kadar hemoglobin yaitu < $11 \mathrm{gr} / \mathrm{dl}$ maka hal tersebut akan mengganggu fungsi kognitif pada seseorang seperti responden tidak tahu sekarang bulan apa, tidak tahu berada diruangan apa, hanya bisa menyelesaikan satu kali mengambil kertas dengan tangan kanan dan tidak di lipat serta juga tidak meletakan di lantai, dan responden juga tidak mampu mengikuti mengulang membaca tulisan yang dikertas dengan memejamkan mata, sehingga kejadian anemia berhubungan dengan fungsi kognitif.

\section{SIMPULAN}

Berdasarkan hasil penelitian disimpulkan terdapat hubungan anemia dengan fungsi kognitif pada pasien yang menjalani terapi hemodialisis di RST Dr. Reksodiwiryo Padang. Diharapkan perawat dapat memberikan edukasi pada pasien hemodialisis dalam mengatasi kondisi anemia dan mempertahankan fungsi kognitif normal. Perawat juga dapat memberikan stimulasi kepada pasien untuk mengingat hal-hal yang mudah diingat seperti mengingat hari, tanggal, dan mengingat nama anggota keluarga sehingga hal tersebut melatih daya ingat pasien.

\section{UCAPAN TERIMAKASIH}

Ucapan terima kasih diucapkan kepada Direktur RS Dr. Reksodiwiryo Padang, Kepala Ruangan dan perawat ruangan hemodialisis, pasien yang telah bersedia menjadi responden serta pihak terkait yang telah memberikan dukungan dan bantuan dalam pelaksanaan penelitian.

\section{DAFTAR PUSTAKA}

Astrini, W. G. A., Hasibuan, P., \& Irsan, A. (2013). Hubungan Kadar Hemoglobin, IMT dan Tekanan Darah dengan Kalitas Hidup Pasien Gagal Ginjal Kronik yang Menjalani Hemodialisis di RSUD Dokter Soedarso Pontianak Bulan April 2013 [Tanjung Pura]. In Journal of Chemical Information and Modeling.

https://doi.org/10.1017/CB097 81107415324.004

Babitt, J. L., \& Lin, H. Y. (2012). Mechanisms of anemia in CKD. Journal of the American Society of Nephrology, 23(10), 1631-1634.

https://doi.org/10.1681/ASN.20 11111078

Baykan, H., \& Yargic, I. (2012). Depression, anxiety disorders, quality of life and stress coping strategies in hemodialysis and continuous ambulatory peritoneal dialysis patients. Klinik Psikofarmakoloji Bulteni, 22(2), 167-176. https://doi.org/10.5455/bcp.20 120412022430

Black, \& Hawk. (2014). Keperawatan Medikal Bedah. Elsevier Inc.

Brunner, \& Suddarth. (2014). 
Keperawatan Medikal Bedah. EGC.

Halgin. (2010). Psikologi Abnormal (Perspektif Klinis Pada Gangguan Psikologis). Salemba Medika.

Herman, I., Yonata, A., Tjiptaningrum, A., Berawi, K. N., Kedokteran, F., Lampung, U., Ilmu, B., Dalam, P., Kedokteran, F., Lampung, U., Klinik, B. P., Kedokteran, F., Lampung, U., Fisiologi, B., Kedokteran, F., Lampung, U., \& Moeloek, A. (2015). Hubungan Lama Hemodialisis dengan Fungsi Kognitif Pasien Penyakit Ginjal Kronik yang Menjalani Hemodialisis di RSUD Abdul Moeloek Bandar Lampung The Relationship between Duration of Hemodialysis and Cognitive Function Chronic Kidney Disease Patient in Hem. 7, 47-53.

Jung, S., Lee, Y. K., Choi, S. R., Hwang, S. H., \& Noh, J. W. (2013). Relationship between cognitive impairment and depression in dialysis patients. Yonsei Medical Journal, 54(6), 1447-1453.

https://doi.org/10.3349/ymj.20 13.54.6.1447

Kementrian Kesehatan RI. (2013). Riset Kesehatan Dasar. Balitbang Kemenkes RI.

Kementrian Kesehatan RI. (2018). Riset Kesehatan Dasar. Balitbang Kemenkes RI.

Kurella, M., Chertow, G. M., Fried, L. F., Cummings, S. R., Harris, T., Simonsick, E., Satterfield, S., Ayonayon, H., \& Yaffe, K. (2005). Chronic kidney disease and cognitive impairment in the elderly: The Health, Aging, and Body Composition study.
Journal of the American Society of Nephrology, 16(7),

2127-2133. https://doi.org/10.1681/ASN.20 05010005

Listiyana, A. D., Mardiana, \& Prameswari, G. N. (2013). Jurnal Kesehatan Masyarakat Andalas. Obesitas Sentral Dan Kadar Kolesterol Darah Total, 9(1), 37-43.

Murray, A. M., \& Knopman, D. S. (2010). Cognitive impairment in CKD: No longer an occult burden. American Journal of Kidney Diseases, 56(4), 615-618.

https://doi.org/10.1053/j.ajkd.2 010.08 .003

Nopriantha, M., \& Kuswardhani, R. T. (2018). Korelasi antara kadar hemoglobin dengan status kognitif pada pasien geriatri di RSUP Sanglah. Jurnal Penyakit Dalam Udayana, 2(1), 15-18. https://doi.org/10.36216/.jpd.v2 i1.41

Palawe, P. C., \& Rotty, L. W. A. (2016). Hubungan Kadar Hemoglobin Dengan Fungsi Kognitif, Kualitas Tidur Dan Lama Rawat Inap Pasien Lanjut Usia Di Rsup Prof. Dr. R. D. Kandou Manado. E-CliniC, 4(1). https://doi.org/10.35790/ecl.4. 1.2016.10944

Papalia. (2009). Perkembangan Manusia. Salemba Medika.

Putri, N. K. (2015). Hubungan Antara Tingkat Depresi Dengan Kualitas Hidup Pasien Chronic Kidney Disease yang Menjalani Hemodialisis di RSD dr. Soebandi Jember. Universitas Jember, 4(2), 210-217. http://repository.unej.ac.id/123 456789/71250 
Rodríguez-Sánchez, E., Mora-Simón, S., Patino-Alonso, M. C., GarcíaGarcía, R., Escribano-Hernández, A., García-Ortiz, L., PereaBartolomé, M. V., \& GómezMarcos, M. A. (2011). Prevalence of cognitive impairment in individuals aged over 65 in an urban area: DERIVA study. BMC Neurology, 11(1), 147. https://doi.org/10.1186/14712377-11-147

Septiwi, C. (2011). Hubungan antara Adekuasi Hemodialisa dengan Kualitas Hidup Pasien Hemodialisis di Unit Hemodialisis RS Prof. Dr. Margono Soekarjo Purwokerto. Universitas Indonesia. 